\title{
From the Right to Mobility to the Right to the Mobile City: Playfulness and Mobilities in Bogotá's Cycling Activism
}

\begin{abstract}
This paper takes cycling activism in Bogotá (Colombia) as a point of departure to conceptualise the right to the mobile city. Mobility is a key site of intervention for claiming the right to the city, but has so far only been considered in terms of access to the city. Such a reading obscures the ways in which mobile practices themselves can be exercises in participation, appropriation, and management of urban space. In examining biketivists' playful mobilities, I emphasise the centrality of mobility in the production of the city. Foregrounding play as a means to assert use value over exchange value in the city allows for a non-utilitarian understanding of mobility and a reconceptualisation of the right to mobility along Lefebvrian lines. However, playful practices can also produce spaces of exclusion, and nuance is necessary to avoid totalising accounts of cycling politics.
\end{abstract}

Key words: right to the city; mobilities; Bogotá; cycling; play

'Could play be the starting point from which we could envisage the metamorphosis of the everyday?' (Lefebvre 2014a:433)

\section{Introduction}

The turn of the century has seen renewed scholarly interest in the right to the city. As the neoliberalisation of urban space pushes into new frontiers, novel challenges for democratic life in the city emerge and Henri Lefebvre's critique of the encroachment of urban life by capitalist interests resonates with activists and academics more than ever. However, it is not until recently 
that transport and mobility have been scrutinised through this lens. Authors concerned with the right to mobility rightfully underscore the importance of access, of getting to the city, as a prerequisite for participation in urban life. Yet, some of this literature continues to ascribe a functional role to transport: that of moving bodies between the fixed spaces of the city. In doing so, it glosses over the insights generated within mobilities thinking about the significance of movement itself as a means for life in the city, implicated in the production of space. Drawing on research conducted in Bogotá, Colombia, I take the city's cycling activist (biketivist) movement as a point of departure to explore what a mobilities reading can do for the right to the city. I emphasise the role of playfulness in urban space to argue that, in foregrounding play, joy, and celebration, certain kinds of mobilities helps us move from the right to mobility towards a right to the mobile city.

I begin with a discussion of the right to the city and playfulness. While geographers have started to take play seriously as a mode of protest, few of these discussions draw explicit links to the right to the city (though see: Morhayim, 2018). Conversely, analyses of the right to the city seldom engage with the playful dimension of Lefebvre's proposal. I follow with a review of how the right to mobility has been conceptualised, and the possibilities that a mobilities perspective opens up for the right to the city. Playfulness and non-commodified leisure are at the centre of the activisms I describe in the following section. I frame Bogotá's biketivism in the context of the city's celebrated public space and transport policies, challenging the degree to which they contribute to the right to the mobile city. I focus on a specific kind of activism, cycling colectivos (collectives), and their playful practices to make a case for playful forms of mobility as valuable ways of appropriation and production of the city as oeuvre.

\section{From the Right to Mobility to the Right to the Mobile City}

\section{Rescuing play in the right to the city}

Fifty years since its publication, Henri Lefebvre's Le droit à la ville (1968) remains a relevant framework through which most contemporary urban problematics can be analysed. Housing, public space, information technologies, and urbanism in the Global South feature in a recently published edited volume that is testimony to the enduring centrality of this work (Verso Books, 2017). Meanwhile, the notion of the right to the city continues to generate enthusiasm among urban social movements, and it is also being re-worked by actors seeking its institutionalisation (Mayer, 2009; UN-Habitat, 2016). The question of mobility's relationship to the right to the city, however, has only recently been addressed (Attoh, 2017; Verlinghieri \& Venturini, 2018). This oversight begets 
further exploration. Certainly, access to the city is fundamental for the exercise of the right to the city. Going further, as a place-making exercise, urban mobility ought to be conducive to the realisation of the right to the city in its fullest expression.

In its simplest formulation, the right to the city is the right of urban inhabitants to fully participate in the production of urban space, and to appropriate space and use it to meet their needs. More than this, the right to the city must be understood through the distinction between 'the city' and 'the urban': where the former refers to the capitalist city characterised by the primacy of exchange value, 'the urban is more or less the oeuvre of its citizens' (Lefebvre, 1996, p. 117); and the right to the city is the right to urban life: 'to renewed centrality, to places of encounter and exchange, to life rhythms and time uses, enabling the full and complete usage of those moments and places, etc.' (Lefebvre, 1996, p. 179). Thus, while the right to the city can be read as a concrete material claim and as an issue of distributive justice (Harvey, 2008), it also entails citizens' abstract claim to appropriate space, time, the body, and desire, and not be alienated from the urban life they have created (Lefebvre, 1996). Lefebvre's politics hence rest on the notion of autogestion of urban space through its appropriation and production beyond state-sanctioned rights or guarantees, a political strategy which 'could help push the contradictions between use value and exchange value to their limit, restoring primacy to use value' (Gray, 2018, p. 329). As such, the right to the city is an openended project where the urban is continuously reworked and negotiated by urban inhabitants.

Lefebvre points to play as one of the means to assert use value over exchange value in the city: 'the ludic in its fullest sense of theatre, sport, games of all sorts, fairs, more than any other activity [emphasis added] restores the sense of oeuvre... prioritizes time over space, appropriation over domination' (Kofman \& Lebas, 1996, p. 19). Leisure, Lefebvre argues, exists in a dialectical relationship with work and daily life. It is a "critique of everyday life from within: the critique which everyday life makes of itself, the critique of the real by the possible and of one aspect of life by another' (Lefebvre, 2014, p. 9). Such a critique is directed towards the colonisation of everyday life by capitalism - namely, the fragmentation of time and space to serve the goals of capital accumulation. Because some forms of leisure exist in opposition to the instrumentality of life structured around productive work, they are conducive to de-alienation; the intensification of the possibilities for encounter; and to the appropriation of space through its free, unmediated use. As such, they help reveal what is possible in urban society, and actualise it.

Two other influential accounts of play's role in society are Johan Huizinga's and Roger Caillois's. Both authors move beyond functionalist perspectives on play and dislocate it from childhood to 
account for the continuation of playful activity in adulthood. Huizinga (1949) defines play as a voluntary, free activity sitting outside "ordinary" life. It is "not serious" yet absorbs the player completely; and it is disinterested, insomuch as it does not satisfy any immediate practical needs. Caillois' work develops on Huizinga's to deliver a typology of games and play. He defines play as a make-believe, free activity that unfolds within limits of space and time; of indeterminate outcome; unproductive insomuch as it creates no goods or wealth; it is governed by rules (Caillois, 2001). More than this, for Caillois play is subvervise and entwined with issues of power (Shepard, 2011). Most authors drawing on play exalt this revolutionary potential, but for this very reason play ought to be further scrutinised to tease out the configurations of power it can reinforce or bring into being (Mott \& Roberts, 2014).

These non-utilitarian views on play rescue play in adulthood emphasising its conduciveness to the exploration and pursuit of pleasure, and the release from the instrumentality of social interactions and reasons for movement. While play is light-hearted and 'make believe', it can also be serious and political. Hence, while play was once the domain of children's geographies, it is now being embraced elsewhere in the discipline by authors who emphasise the ethical, political, and subversive role of the ludic in adult life (Woodyer, 2012). Geographic work on adult play encompasses videogaming (Ash \& Gallacher, 2011); games and the city (Vanolo, 2018); and war and geopolitics (Klinke, 2016). Others have noted play's strategic use as a form of protest, where it is employed to "imagine and enact new selves, social relationships, and means of politics" (Shepard, 2011, p. xv) and helps gel movements together (Crossa, 2013; Flusty, 2000). Research on urban play is burgeoning, emphasising that certain characteristics of cities (diversity, density, and the built environment) inhibit or facilitate play, and may harbour the potential for political transformation (Mann, 2015; Stevens, 2007; Walz, 2010). Within this work, certain forms of moving in the city, like parkour (Ameel \& Tani, 2012), skateboarding (Stratford, 2016), and cycling (Morhayim, 2018), have been examined to interrogate the possibilities afforded by infrastructures beyond the intentions of urban planners. What these analyses reveal, is that the unruly appropriation of space for play does away with the rigidity of the organisation of urban space and thus helps to de-commodify space, restore its use value, and '...create forms of order that might be temporary but over which we exact some control; we use it to give expression to a desire to enliven the banal, breathe life into the fabric of existence, and enjoy moments of freedom and reflection' (Stratford, 2016, p. 352). Yet, for all the threads that tie playfulness to the right to the city, few accounts have given due attention to the political and transformative potential of play as part of claims to the right to the city. While the two have loosely been brought together (Furness, 2007; Morhayim, 2018), further analysis is warranted if we are to reframe everyday mobility along playful Lefebvrian lines 
and heed the call to "replace travel as adjunct to work with travel as pleasure" (Debord, 2006, p. 148). As I intend to argue, the encounters staged by biketivists in Bogotá elucidate how such a decoupling is possible.

\section{Mobilities and the Right to the City: Towards a Productive Dialogue}

Scholars have recently started to consider the 'right to mobility', underscoring that access to the city is a prerequisite to appropriate urban space and participate in urban processes, including the exercise of democracy through simply being in public (Van Neste \& Sénécal, 2015; Verlinghieri \& Venturini, 2018). In these analyses the right to mobility is read as a 'functional part of the right to the city [emphasis added]' (Verlinghieri \& Venturini, 2018, p. 127). That is, mobility is a means to access the city rather than a transformative, world-making, political practice in its own right. Yet, what is at stake in the right to the city is not merely the right to visit the city, but the city itself.

Conceptualised in this way, the right to mobility appears to have glossed over the insights generated by mobilities thinking (Cresswell, 2010; Sheller \& Urry, 2006). This is perhaps the case due to its roots in the right to the city, which has remained static in its spatial focus, hardly entertaining dialogue with the well-established mobilities tradition. As such, the right to mobility assumes that the exercise of the right to the city unfolds in a bounded space that people travel to, and the right to mobility guarantees the possibility of participating over there. I wish to challenge this conceptualisation, arguing that while access to the city is indeed important, the 'right to the mobile city' - that is, the marriage of mobilities and the right to the city - sheds light on the way in which mobile practices themselves are exercises in participation and appropriation. Already, some have paved the way in this direction, attending to how young men and women's movement and circulation are ways of asserting their belonging in, and making claims to, the city (Caldeira, 2012; Gamble, 2017; Simone, 2005). Furthermore, in his work, Kafui Attoh (2017) argues that access to the city is insufficient if it prevents individuals from being part of the public through 'enforced privatised isolation'. This work traces the contours of a right to the mobile city that acknowledges that how we move in the city also begets critical scrutiny when thinking about the mobility-right to the city nexus. However, a more sustained dialogue between the two bodies of literature is still in order.

As an entanglement of movement, representation, and practice, mobility is politically meaningful and subject to contention, insomuch as it is implicated in the production and distribution of power (Cresswell, 2010). Based on the premise that social relations unfold while on the move, mobilities 
scholarship has raised awareness about the ways in which power is embodied and experienced in motion. Nowhere is this more apparent than in cities, where mobility characterises our experience of everyday life. As noted by mobility justice scholars, urban mobility is both reflective of and reproduces existing power asymmetries along racial, gendered, and class lines, such that certain spatial forms enable or constrain mobility in uneven ways (Sheller, 2018). Such asymmetries have been keenly noted in critical accounts of automobility (Henderson, 2006; Manderscheid, 2014; Urry, 2004) which highlight automobility's capacity to '[reconfigure] urban life, with novel ways of dwelling, travelling, and socialising in, and through, and automobilised time-space' (Sheller \& Urry, 2006, p. 209) to the detriment of other forms of urban dwelling.

These asymmetries have also moved individuals to mobilise in cities around the world, giving shape to an important tradition of transport-related protest, not least in Latin America (Sagaris \& Landon, 2017; Servín-Ugarte, 2014; Sosa López, 2017). Cycling protest, specifically, has received attention from a quickly expanding vélomobilities field which has empirically turned to cities of the Global North to conceptualise it as a contentious issue in its own right (Aldred, 2013; Cupples \& Ridley, 2008; Furness, 2007; Hoffmann, 2016). Meanwhile, a critical engagement with cycling and politics in the Global South is overdue to unpack the manifold ways in which cycling becomes embedded in the urban landscape (though see: Gamble, 2017; López León, 2016; Rinaldi, 2018). In all, while explicit connections with the right to the city have been suggested across the literature, they remain to be elaborated (though see: Raquel, 2018). In embracing thinking on urban play, this essay follows others who have conceptualised bicycle resistance as a form of playful prefigurative action (Furness, 2007; Morhayim, 2018). However, it moves forward by explicitly tracing these activities back to the right to the city and redirecting the right to mobility towards a more Lefebvrian trajectory.

\section{Contextualising cycling protest in the 'cycling city'}

The existence of a cycling activist movement is at odds with Bogotá's status as an example of best practice in pro-cycling policy (Montero, 2017). Beginning in the 1990s, mayors Antanas Mockus (1995-1997 and 2001-2003) and Enrique Peñalosa (1998-2000 and 2016-present) developed a series of policies and infrastructures intended to alleviate some of the exclusions and inequalities that plagued Bogotá (Berney, 2013; Galvis, 2014). Their transport policies, specifically the Bus Rapid Transit system and Ciclovía $a^{\mathrm{i}}$, have circulated widely and received world-wide praise 
(Montero, 2017; Wood, 2015). Other measures to promote cycling and address Bogotá's transport problem were driving restrictions to private vehicles, the construction of $295 \mathrm{~km}$ of cycling infrastructure (primarily retrofitted onto sidewalks), and the establishment of a yearly car-free day. Yet, as Laura Cesafsky's research shows, mobility continues to be one of the key problems lived and embodied by bogotanes ${ }^{\mathrm{ii}}$, and is intimately tied to issues of democracy, whereby "the 'failure' of political institutions to remedy traffic in Bogotá has left the problem to linger and nurture democratic life in the form of collaborative and contestatory public practice" $(2017$, p. 6$)$.

Examining Bogotá's biketivism in the way I propose builds on the groundwork laid by Cesafsky and others (Berney, 2013; Galvis, 2014) to challenge the degree to which these top-down interventions actualise the right to the city, not just access to the city. While the right to the city has been a rallying cry for social justice in many cities of Latin America and the Global South (Samara, He, \& Chen, 2013), it has also been in Latin America where most governmental initiatives to institutionalise this right have emerged - from Brazil's Right to the City statute, Mexico City's City Charter, and Ecuador and Bolivia's constitutional recognition of the right to the city. The Mockus and Peñalosa administrations also intended to grant this right to bogotanes, articulating citizenship, public space, and the right to the city: "being a citizen meant a right to public space, while acting within public space taught Bogotanos how to be citizens" (Berney, 2013, p. 154). Hence, their right to the city was a right of citizenship to be accessed via mobility and public space but, as critics argue, this right to the city rested upon the 'correct' use of public space by a specific kind of public: the presence of the poor, homeless, and street vendors was at odds with the production of space in line with a neoliberal agenda of investment-worthy, stable cities (Galvis, 2014).

As far as transport is concerned, state-sanctioned mobility depended on a functional understanding of mobility, underpinned by notions of speed and efficiency, but also increasingly popular notions of urban sustainability and contested claims about the organisation of urban space (Montero, 2017). Infrastructure developments did improve accessibility and guaranteed a 'visiting right' (ie access) to the city, but remain at odds with the Lefebvrian reading of the right to mobility I suggest. Indeed, their top-down character runs counter to autogestion as the practical means to achieve the right to the city (Purcell, 2014). If the right to mobility entails the provision of transport services to access the city, the right to the mobile city is the right of citizens to appropriate, produce, and manage urban mobility for themselves to meet the needs and desires that functionalist state planning cannot deliver: the need for play, creativity, surprise, encounter, and the need to overcome alienation in everyday life. Hence, it involves appropriating physical space to challenge the spatial and temporal ordering of mobility- the parking lot, the airport drop-off lane, the motorway, and the alley are all 
susceptible to being appropriated for a more diverse set of mobile practices than the motorised vehicle allows. In turn, it calls for remaking the space-times of mobility as sites of encounter and meaningful interaction, and reframing the terms of the politics of mobility to produce mobility anew. Its infrastructures, symbols, practices, and norms come to be managed by citizens in their own terms and, as playful movement unfolds, the internal rules of the games they stage come to take the place of the norms that govern locomotion. As a form of resistance, the right to the mobile city can draw attention to the insufficiencies of state planning for non-motorised mobility. As an urban political project, it teases out the possibilities latent in the city by opening up the street to uses more diverse than currently afforded without relying on the state, thereby restoring the use value of infrastructures hitherto monopolised by automobility.

This paper draws on research conducted in Bogotá over the course of six months in 2015. During this period I undertook a cycling participant-ethnography (Spinney, 2009) where the bicycle became my primary means of transport; participated in rides several times per week with groups based in Usaquén, Chapinero, and Engativá (north and north-western Bogotá); attended activist meetings, and weekly Ciclovía. Immersing myself in Bogotá's cycling culture allowed me to become attuned to the joys and struggles that motivate biketivists. I was challenged to discover the physical capacities enabled by the bicycle, visit parts of Bogotá unknown to me, and come to know them through cycling with others. I also draw on thirty-five semi-structured interviews ${ }^{\text {iii }}$ with biketivists, cyclists, and officials from the National Ministry of Transport, the District Institute for Recreation and Sport (IDRD), and the Office for Culture, Recreation and Sport. The extension of the city and the security landscape in Bogotá were important limitations for conducting this research. As a woman, cycling alone at night time from my base in the north imposed limits on my engagement with activism in other parts of the city. Therefore, partaking in rides that brought several colectivos together, as well as interviews with leaders from Suba (west), Kennedy and San Cristóbal (south) became a valuable resource to access the experiences of biketivists beyond the limitations I encountered.

I treat Bogotá not as a case study - an instance or example of something-, but as a case which elicits judgement and reflection in a manner that is open ended and suggestive (Berlant, 2007). The case is not invoked to provide an example of a generalisable phenomenon, but as a point of departure from which to think through the right to the city with mobilities, and foreground the elements of playfulness embedded in The Right to the City. In his writing, Lefebvre contends that the urban project calls for a new set of approaches and tools. 'Transduction', he proposes, is a political method involving 'closely examining actual-but-inchoate practices that are currently taking 
place in the city, and [extrapolating] them using theoretical reflection to produce, in thought, a more fully developed version of them, a virtual idea (which [Lefebvre] calls 'urban society') that shows us what kind of world they would produce if they were allowed to flourish and pervade the city' (Purcell, 2013, p. 319). In this way, I proceed to derive an argument for the right to the mobile city from the experiences and dialogues entertained with Bogotá's colectivos.

\section{The Right to the Mobile City}

Bogotá's colectivos

At the time when this research was conducted, cycling activism in Bogotá consisted of an array of initiatives including start-ups; charities; cycling schools; women's groups; and the bicycle colectivos which are at the centre of this analysis (Alcaldía Mayor de Bogotá, 2014). The overarching goals of the movement are the achievement of widespread social recognition of cyclists as legitimate road users and the transformation of Bogotá into a more convivial city through interventions in mobility. Certainly, 'cycling activist' is a fuzzy category that relies as much on selfidentification as in the acknowledgement of others, and it is further complicated by the movement of individuals between government, business, and civil society organisations. For the purposes of this essay, I use the term 'biketivist' to denote the leaders and organisers of colectivos, who have their own specific aims and strategies that set them apart from other kinds of activisms. They are groups of cyclists who organise night-time cycle rides with the aim of 'rediscovering', 'appropriating', and enjoying the city. In this sense, biketivism is less about cycling itself, than it is about making claims over the spaces of the city. Each is composed of a core group of organisers people who identify as and are recognised by others as activists-, and their activities, promoted via social media, are open to anyone who has the possibility (material and bodily) to participate. In Bogotá, as elsewhere, biketivism is a distinctively gendered activity, with mostly men occupying leadership positions, even as an important number of women participate in rides and activities. This raises a number of questions about the cycling movement that are only beginning to be addressed by activists, as I will discuss further on.

Meanwhile, although research in the United States has typified cycling activism as an upper-middle class activity (eg Hoffmann, 2016), colectivos in Bogotá are evenly spread throughout the city, from the affluent north and the middle-class neighbourhood of Teusaquillo, to the working class neighbourhoods of Kennedy, Tunal, and Ciudad Bolívar (Defelipe, 2015). In a city as vast as 
Bogotá, having multiple groups facilitates participation that would otherwise be precluded by long distances and dangerous conditions for cycling - particularly at night-time. The proliferation of groups also means that anywhere between a dozen and several hundred cyclists participate on any given night of the week, and it entails that, rather than a large city-wide manifestation like Critical Mass, bogotanes organise at the scale of the locality ${ }^{\text {iv }}$, giving form to a movement that is reflective of the socio-economic divisions that are inscribed in the city's social and material life.

Difference makes a difference in biketivism, and it does in terms of the diverse needs of each locality vis-à-vis cycling and mobility and the reasons that drive people to uptake cycling; they make a difference in creating a sense of belonging, sustained engagement with the community, organising activities in familiar and meaningful places, shaping people's perception and disposition towards cycling; and they make a difference at the time of riding together and collaborating. Biketivists commonly speak of the intention of coming into contact with the "different realities" that exist in Bogotá, and seek to engage with the multiple possibilities that exist in the city. Hence, they commonly organise activities with colectivos from other parts of the city. By way of example, on the evening of $22^{\text {nd }}$ October, with the explicit intention of exploring the depths of Engativa (in northwestern Bogotá), half a dozen colectivos from the north and south met under the bridge at the intersection of $86^{\text {th }}$ Avenue and $63^{\text {rd }}$ Street to cycle together to the western limit of the city in a massively attended group ride (Field diary $22^{\text {nd }}$ October 2015). This purposeful staging of encounters is valuable insomuch as the right to difference is pivotal to the right to the city: 'urban life', Lefebvre (1996:75) states, 'suggests meetings, the confrontation of differences, reciprocal knowledge and acknowledgement (including ideological and political confrontation), ways of living, 'patterns' which coexist in the city'. This is, perhaps, one of the greatest appeals of colectivos: encountering others and getting to know the city in an enjoyable way were cited by cyclists as the primary reasons to partake in rides.

In the context of Bogotá's urban politics, colectivo leaders understand their endeavour to be political, implicated in asserting the right to the city irrespective of the seating Mayor and concessions made by the state. Depending on the administration, they oscillate between a more collaborative or oppositional stance, but they are nevertheless careful to differentiate between the politics of cycling and party politics, and share the view that "public policy doesn't have to be topdown. It has to have participation. Thinking about the political... is thinking from the place of citizens" (Field Diary 28 September 2015). Their reading of the right to the city is underpinned by the questions "who is the city for?" and "how can we change our relationship to the city?": 
'[Ours] is a young people's colectivo that believes in the right to the city, and to claim that right to the city it uses the bicycle as a political instrument, not just as a hobby or for recreation. [...] we see the bicycle as more than two wheels that will get me somewhere quickly or to do exercise. It really is an element that helps move forward a bit towards producing territory; new relations. Like, we really begin to have a new perspective of the city; it, like, helps us relate to the city itself more, yes?' (Interview 15/11/15)

Thus, rather than making formal claims to the state for more infrastructure, they act by taking to the streets en masse and demonstrating through their practices that there are alternative ways of being together on-the-move. Their activities foreshadow the possibilities that emerge when everyday mobility is refigured in playful terms, and when citizens take charge of the times and spaces of mobility. While in some respect Bogotá's Ciclovía serves to promote equity and encounters with difference (Torres, Sarmiento, Stauber, \& Zarama, 2013), it constrains space-times of mobile enjoyment to specific state-sanctioned streets and schedules, leaving unsatisfied the desire for creativity, appropriation, and play that moves biketivists to produce mobile spaces and take the right to the city in their own terms.

\section{Mobility and its Discontents}

Despite the administration's efforts to provide cycling infrastructure and advance pro-cycling policy, activists continue to have an oppositional stance towards the ordering of mobility in Bogotá. This is because, despite the city's celebrated cycling programmes, activists perceive these efforts as insufficient to subvert the dominance of automobility. They decry the deleterious effects of the car on the relationship between bogotanes and the city, and between each other. Hence, their claims are irreducible to more infrastructure to move from A to B: they are about "the mobility problem" (Cesafsky, 2017) - the lived, highly embodied individual and collective experience of struggling to navigate the city -, and they are about life in the city.

'Bogotá has become a network of highways. [...] we have become a city that... for example, you leave your house, you want to lock yourself up in your car or on the mode of transport you've chosen and not see anybody, spend as little time as possible on the street and reach a destination that is usually a shopping mall or your workplace' (Interview on 11/11/15).

'We have a theory, which is that when we go around in a motorcycle, a car, a bus, our contact with others is mediated by an object. [...] When you cycle, you become more responsible for others, there 
is a person beside you' (Interview on 16/12/15).

'when people use motorised forms of transport, or mass transport, they do so through primary arteries. And primary arteries, well, they're important, but they're not the whole city. [...] Oftentimes the car... you don't see everything that is around you. You are not aware of the realities of others' (Interview on 6/11/15).

These testimonies echo the numerous critiques to automobility that centre on alienation as one of its primary effects (Debord, 2006; Furness, 2007), including Lefebvre's own: the relationships forged between people and their cars, he wrote, produce a pattern of behaviour resulting in reification of activity - 'when activity and consciousness become 'things', and allow themselves to be taken over by "things" (Lefebvre, 2014, p. 502). Relationships mediated by things, alienation from others, from the city, and from urban life cannot be remedied through infrastructure alone. The yearning for more intimate relationships with one another and the city begets novel forms of organisation that satisfy these desires. In this context, the collective ride appears as a mobile experience of public play that may help overcome this alienation: it heightens the senses, disrupts the banality of everyday life, and stimulates the imagination (Amin \& Thrift, 2002).

Dissatisfaction with automobility is not limited to its effects on urban life. Its materialities and practices, and its articulation with vélomobility, are also called into question. Cycling infrastructure notwithstanding, the possibility for free, unmediated and spontaneous movement is restricted by the fragmentation of space on the basis of vehicular capacity. Hence, when they invoke notion of a "right to space" and the idea of "sharing road space", activists certainly speak of distributive justice. Yet, their discourse also touches upon the tension between use value and exchange value. Automobility and vélomobility are nestled in the neoliberal paradigm of urban competitiveness to which Bogotá is no stranger. The policies and developments of the 1990s for which Bogotá is celebrated were underpinned by the desire to transform Bogotá into an attractive city for investment and business (Berney, 2013). Where certain mobile practices are deemed unfit for these purposes, others, like speedy and efficient movement, are privileged and encouraged in the making of a competitive city. This can sometimes mean cycling and activism itself is absorbed into circuits of capital accumulation (Stehlin, 2015). In this way, the use value and function of streets as spaces for congregation and encounters between strangers are subsumed to the exchange value demanded by urban competitiveness.

Hence, activists' claims do not rest at infrastructure because infrastructural fixes continue to restrict the movement of people along pre-determined conduits, maximising automobile speed and 
undermining other forms of mobility. Vélomobility is retrofitted onto automobility much in the same way cycle paths were onto sidewalks, confining non-motorised movement to the leftover spaces of the city. As such, the "mobility problem" in Bogotá is treated as one of traffic circulation, and traffic circulation is "the opposite of encounter: it absorbs the energies that could otherwise be devoted to encounters or to any sort of participation" (Kotányi \& Vaneigem, 2006, p. 183). Simone (2005, p. 517) proposes another kind of circulation, one that is conceptually closer to the right to the mobile city and helps us envision the possibilities for other kinds of mobilities: "circulation refers specifically to a practice of lateral, transversal movement, whereby individuals attempt to get out of their neighbourhoods and familiar social relationships, to demonstrate a capacity to navigate a wide range of different quarters and an availability to engage in different activities, as well as an availability to become parts of different stories, games, transactions being elaborated by others elsewhere in the city." Biketivists hence take to the streets to circulate; to experiment with the possibilities for everyday life in the city, and work to decouple travel as adjunct to work and make it instead about the pleasure of cycling (Furness, 2007). Conceptualising their playful tactics as appropriation and production of the mobility against the grain of automobility yields a perspective of the right to the city that I term the right to the mobile city.

\section{Playful mobility for the right to the mobile city}

Nearly every night of the week there are colectivos cycling around Bogotá, drawing people to the windows of their apartments to gaze in amazement as the collective achievement of bodies typically young and able bodies_-, bicycles, lights, whistles, bells, and music circulating, like "a work of art", as described by an activist (Interview on 17/11/2015). However, it is one thing to witness a ride, and another to experience its effervescence. Like the carnival and fête, which restore value by means of unproductive pleasure that is free to all (Merrifield, 2013), the ride is shrouded in excitement, enveloped by music and laughter, and underpinned by the will to enjoy outside the parameters of everyday life: "Knowing that I am in a moment of feeling alive. Leaving my job, my activities... finding a space different from the activities that constantly take place in my life" (Interview on 11/11/2015, emphasis added). Rides assemble at points indicated by colectivos typically plazas, parking lots, or parks - and for anywhere between two and five hours (including breaks and post-ride activities) they trace trajectories meant to instil a sense of appropriation, discovery, and belonging in participants. They are designed to be different each time; carefully crafted by organisers, sometimes with the aid of colectivos in other parts of the city; they can follow 
themes, like connecting the city's public libraries; or they can be designed to surprise and amaze, like the ride to the airport. The point is, as several leaders commented, to get to know the city and the difference that exists therein; and to re-imagine the spaces of the city, and awaken a sense of wonder and accomplishment.

'The red-light district, the wetlands. Who goes to a wetland at night? And on a bike? You'll get mugged. Or maybe, perhaps you didn't even know there is a wetland behind your house. There are things that impact people, like reaching Eldorado Airport from $96^{\text {th }}$ Street, to them it's... well, the people who come to the ride are not Nairo, or Rigoberto, or Mariana Pajón , but people who are getting started. Reaching these places to them... or, the cemeteries of the north? They think it's amazing! Or the red-light district... places where people don't go. And we don't decide the route because, if I say, during the day it might sound very boring. But at night, it's very different from the daytime' (Interview on 17/11/15).

These effects, however, are mediated by classed and gendered experiences of the city. A route designed to cross the red-light district raises questions about urban exploration as a gendered practice that relies on and reproduces patterns of unequal access to the city to provoke wonder in riders; and complicates the extent to which rides can meaningfully engage with difference if such inequalities are taken for granted.

Still, the ride will invariably elude the common sense of onlookers: it is neither utility nor sportive cycling, nor yet part of Ciclovía. Rather than keeping to the state-sanctioned space-times of leisurely cycling or utilitarian movement, cyclists take to the streets at night to appropriate the infrastructures of automobility and produce urban mobility in a way that reimagines the city in motion. This opens up a wealth of possibilities, for the multiple 'loose spaces' of the city provoke the imagination and incite cyclists to move in ways different from those intended by planners (Stevens, 2007), more along the lines of their heart's desire. This plays out in a number of ways. No longer confined to the cycle path, nor threatened with collision with a speedy vehicle, cyclists are free to experiment with infrastructures and demonstrate that their meaning and function emerge relationally: the echo of our shouting voices while we cycle below an overpass reverberates to infuse the night with the distinct sound of enjoyment; the skilful are able to experiment hopping on and off sidewalks, perform 'wheelies' or ride hands-free; the materiality of the bike, whether fixedgear or a BMX bicycle, affords different opportunities for motion that are also tested in the space of the ride. Moreover, one is occasionally overcome by joy and the desire to move erratically, spontaneously: racing off to the head of the ride or zig-zagging through the group to get closer to the music, or to find a familiar face. These highly-embodied and sensorial playful tactics serve to 
'overcome alienation, by bringing direct bodily engagement with the material world and a sense of agency within the social world' (Stevens, 2007, p. 224). More evidently, appropriating the street to give way to play, to unproductive energy expenditure, is an embodied critique of the primacy of exchange value: once the conduit for efficient movement, the street is resignified as the place of play and encounter-on-the-move and experimentation with the body-bicycle.

Games, Caillois and Huizinga theorised, have rules that govern their function to a greater or lesser degree. The ride, too, has an internal set of rules and though they vary slightly from group to group, they always serve a dual purpose: first, it ensures the safety of participants and the smooth unfolding of the ride. Equally, these are the rules that now govern locomotion in that particular space-time and allow biketivists to produce mobility in their own terms. In other words, through these rules cyclists manage mobility for themselves and they allow them to lay claims to the mobile city. Two moments of the ride suffice to illustrate: the practice of "corking" traffic (Ferrell, 2011) entails breaking away from the group to block oncoming cars while the rest of the group cycles across an intersection, even as the light turns red. Corking unfolds spontaneously - anyone can do it -, and it does away with the symbols and norms of vehicular traffic circulation to manage mobility in accordance with the needs of the group. Autogestion might also entail managing the rhythms of mobility and rhythm, Lefebvre (2004) notes, is one of the dimensions of social order through which change can be brought about: "the leader called for "dos tiempos" ("two times") which I later came to find out means that the group is to wait for two light changes before moving along, in order to wait for those who have stayed behind" (Field Diary 29/10/2015). Thus, cyclists momentarily take over the space, times, and rhythms of mobility to create a different social life, to demonstrate the possibility of managing space and time, not on the basis of abstraction, but as they are lived (Kofman \& Lebas, 1996, p. 33).

These experiences, claims one leader (Interview on 17/11/2015), generate a sense of empowerment and collective self-esteem, which in turn incite positive affect towards the city. This effect stems from the affordances of exploratory play, and harbours the potential to generate enchanting urban experiences through encounters with unfamiliar people, spaces, and sensation (Stevens, 2007). Hence, in bringing bogotanes closer to hitherto untapped experiences, and in generating feelings of affection and wonder towards the city through an embodied engagement with its mysteries, the rides serve to de-alienate the relationship between citizens and their city. And more: as an urban experiment, the ride is also an expression of use value that restores the sense of the oeuvre in the city through the production of mobilities that allow people to experiment with the body, the bicycle, and city in a manner that is free and unmediated by the imperative of exchange value. 
The reliance on play does not end at staging encounters where people are able to experiment with movement. Sometimes, people get together to ride and play. One activist spoke of the 'traditional games' ride his group organises:

'the theme is 'have fun like a kid during adult hours'. So, we have a yermis ${ }^{v i}$, our yermis, and its a giant travel bag where we have one-hundred thousand sticks and many balls, and we have twohundred people play yermis in Bolívar Square... or we play 'hot belt' in Independence park; or there is a night which is sports night and we go to [a part of the city] where there are basketball, futsal, volleyball, hockey, everything. And people go and appropriate these spaces' (Interview on $15 / 12 / 2015)$.

Similarly, rides might culminate with a surprise performance or party: an 'illuminati' themed ride took cyclists to a large empty square, where clowns, jugglers and fire-breathers entertained the cyclists who had decked out their bikes in an attempt to win the prize for the best-lit bicycle. In the meantime, the music of the ride enlivened the emptiness of the night. Such events inspire creativity and tease the imagination, allowing individuals to appropriate space in a manner that asserts its use value and establishes the centrality of mobile practices in claiming the right to the city.

\section{The limits to play}

'The first time I came out with the group I felt [out of place] because I'm 56 years old, in a group of people that could not have been older than 25 , and I was afraid. So [the leader of the group], very sweet, told me, 'you'll always ride by my side and you'll be alright'. But at some point she accelerated and got ahead, and I fell behind, and that's when I crashed' (Interview on 7/11/15)

While the rides I describe are well attended, it would take great effort to find another person above the age of 50 participating regularly. I only did find one other cyclist who fit this profile. This begets the question, who can play in this way in Bogotá? I have detailed the ways in which biketivists' playful strategies can be interpreted as recuperations of the oeuvre, but an examination of their limitations is in order. Insomuch as play is a world-making activity entwined with issues of power, it is worth questioning how power geometries shape and are re-shaped by playful encounters. I, for one, could not play with everyone since, in Bogotá, this form of participation is constrained by the geographies of crime and fear in the city that can force people to retreat back into their homes; and condition the possibility for moving around and participating (England \& Simon, 
2010). Indeed, however much these activities intend to show that the city is not sinister and unsurmountable, issues of fear, bodily and cognitive capacity, and in/exclusion do preclude participation, and originate in inequalities that draw the boundaries of participation.

Meanwhile, although I have noted that colectivos often explicitly seek to come into contact with difference in the city, the extent to which difference is engaged with can vary. Indeed, contact is not the same as meaningful encounter, nor does it always entail respect for difference (Valentine, 2008). Problematically, some activists incur in a discursive erasure of difference:

"'Oh, so you don't go to the south; you don't go to the north". Let's not talk in these terms anymore, because we are replicating the segregation that's imposed on use by other aspects of the city. Let's break away from that. Let's not talk about estratos, neighbourhoods, north or south. Let's talk about the city" (Interview on 17/11/2015).

Equally, it is not uncommon to hear activists claim that, when we are cycling, "we are all the same". Flattening out difference in this way precludes any possibility of critically engaging with the inequalities of the city beyond transport, as another activist explains:

'this is one of the key debates I have with the cycling discourse. It's very isolated from the other systems of the city. There is great potential in mobility to reduce social segregation. That discourse hasn't even leaked in because it requires greater theoretical development, and a more systemic vision of the city. The closest we find in the cyclist discourse is "cyclists are poor, so if the conditions for cyclists' everyday journeys are improved, it would favour a sector of society that is disenfranchised"' (Interview on 2/12/15).

Herein lies another shortcoming of these spaces: although biketivism has proliferated across the city and consists of groups and individuals from all estratos, a meaningful engagement with the most underserved is hindered by the fact that the leisure time required to be able to participate in the appropriation and production of mobility in this way is out of the reach of many. In Bogotá, as elsewhere in Latin America, the bicycle has historically been the vehicle of the working class (Torres Barragán, 2015), yet those for whom the bicycle is a means for livelihood (there is a running commentary about the bicycle traditionally being seen as the vehicle of "porteros y jardineros" - gardeners and porters) are problematically absent from these activities and their mobile practices overlooked when framing the terms of mobile encounters.

Gender has become a matter of concern in Latin American biketivism in recent years and begets 
commentary (Gamble, 2017). While feminist cyclists have been drawing attention to the power asymmetries extant in biketivism, feminist academics have approached the right to the city highlighting its indifference to gender, which ostensibly shapes participation and citizenship (Fenster, 2005). Methodologically and epistemologically, analyses of urban play and exploration typically foreground the experiences of young men at the expense of the experiences of others who have historically been excluded from, and are less likely to partake in transgressive behaviour, in public space (Mott \& Roberts, 2014). Although the challenge of "how do we get more women to cycle?" runs across biketivism, questions of how the spaces of activism and participation in/exclude women are only beginning to be discussed by biketivists in Bogotá, and further research that examines gendered dynamics in cycling is warranted.

The "right to the city", "the city is for all" and claims about the common good resonate with bicycle discourses elsewhere (Cupples \& Ridley, 2008). These claims paint a picture of vélotopia where 'everyone' can participate, yet the possibility for playing in the way I have described is confined to those who have the material and cognitive means to do so: a bicycle, leisure time, an able body, confidence and competence riding in a group, and the capacity to reach the meeting points at nighttime. In this sense, there are forms of exclusion always already embedded in these practices which (re)produce and centre a very specific type of cycling subject. If at the centre of vélotopia are ablebodied young men, there is a risk that the right to the mobile city will be built to the image and likeness of hegemonic subjects and their practices.

These limitations notwithstanding, these initiatives are valuable insomuch as they pave the way for further interventions to de-alienate urban environments through interventions in mobility. In drawing attention to the uneven ways in which mobility is configured and in producing mobility otherwise, they illuminate what is possible, but the question of who is excluded in the right to the city continues to convolute accounts and experiences of urban politics. As it has now been documented that cycling initiatives can uphold existing inequalities, or give way to new ones (Hoffmann, 2016; Stehlin, 2015), both academics and activists would do well to interrogate these shortcomings if the bicycle is to become an ally in realising a right to the mobile city.

\section{Conclusion: playing in urban space, signs of the urban}

Despite constraints about who can be involved and in what ways, colectivos manifest an important departure from the norms that govern movement in the city. Biketivists ride for the sheer enjoyment 
of cycling, and the thrill of navigating the city at night-time; for the possibility of exploring hitherto uncharted parts of the city, and untapped bodily potential; and for the joy of encountering one another. Here, I have drawn on these experiences to speak back to the right to the city and right to mobility literatures and signpost the way to the right to the mobile city. My argument centres on the importance of mobility for urban politics. Playfulness foregrounds flexibility and creation, and draws attention to the inadequacies of a functional understanding of mobility as providing access to the city. As such, I assert the centrality of citizens' production and self-management of diverse mobile practices in affirming the right to the city. State-sanctioned vélomobility, the product of urban planning, is not enough to satisfy people's need for play, creativity, and the oeuvre; rather, these are stifled by planning centred on automobility. Where citizens cannot move freely and are constrained by the imperatives of automobility, the oeuvre, the city as characterised by use value, cannot come to fruition. Conversely, taking to the streets to stage a night-time ride that facilitates experimentation, enjoyment, encounter, and the coming together of people and the city is an exercise in the production of mobilities otherwise, an assertion of the right to the city through interventions in grassroots mobility. Viewed through this lens, the right to the mobile city is the right of urban inhabitants to seize the existing conduits for motion in the city (appropriation) and become producers of mobility (participation) in ways that are conducive to the urban - mobility like a work of art.

\section{Endnotes}

${ }^{\mathrm{i}}$ Every Sunday and public holiday $119 \mathrm{~km}$ of the city's major roads are closed to motorised traffic for the enjoyment of joggers, skaters, cyclists, etc. Ciclovía lasts between 7AM and 2PM and is attended by approximately 2.5 million people each weekend.

ii Spanish uses gendered nouns and the masculine is the generic form. Rather than defaulting to either masculine, feminine, or the binary "bogotan@s", I follow the call from feminist activists to engage in "linguistic disobedience" and employ "bogotanes" to disrupt gender binaries when speaking about inhabitants of Bogotá. See:

http://revistaanfibia.com/ensayo/manual-de-instrucciones-para-hablar-con-e/

iii All interviews were conducted in Spanish and translated into English by the author.

iv Bogotá is divided into 20 administrative unites called localidades (localities).

v Nairo Quintana, Rigoberto Urán, and Mariana Pajón are famous Colombian professional cyclists.

${ }^{v i}$ Yermis is a traditional Colombian game played in parks, squares, and other open spaces. See: https://journeys.dartmouth.edu/folklorearchive/2016/11/18/yermis/ 


\section{References}

Alcaldía Mayor de Bogotá. (2014). El libro de la bici 2014. Bogotá: Alcaldía Mayor de Bogotá.

Aldred, R. (2013). Who are Londoners on Bikes and what do they want? Negotiating identity and issue definition in a 'pop-up' cycle campaign. Journal of Transport Geography, 30, 194201.

Ameel, L., \& Tani, S. (2012). Parkour: Creating loose spaces? Geografiska Annaler: Series B, Human Geography, 94(1), 17-30.

Amin, A., \& Thrift, N. (2002). Cities: Reimagining the urban. Cambridge: Polity Press.

Ash, J., \& Gallacher, L. A. (2011). Cultural Geography and Videogames. Geography Compass, $5(6), 351-368$.

Attoh, K. (2017). Public transportation and the idiocy of urban life. Urban Studies, 54(1), 196-213.

Berlant, L. (2007). On the Case. Critical Inquiry, 33(4), 663-672.

Berney, R. (2013). Public space versus tableau: The right-to-the-city paradox in neoliberal Bogotá, Colombia. In T. R. Samara, S. He, \& G. Chen (Eds.), Locating right to the city in the global south (pp. 152-170). London: Routledge.

Caillois, R. (2001). Man, Play, and Games. University of Illinois Press.

Caldeira, T. P. R. (2012). Imprinting and Moving Around: New Visibilities and Configurations of Public Space in São Paulo. Public Culture, 24(2), 385-419.

Cesafsky, L. (2017). Divided Together: Traffic and Democratic Life in Bogotá (PhD). University of Minnesota, Minneapolis.

Cresswell, T. (2010). Towards a Politics of Mobility. Environment and Planning D, 28(1), 17-31.

Crossa, V. (2013). Play for Protest, Protest for Play: Artisan and Vendors' Resistance to Displacement in Mexico City. Antipode, 45(4), 826-843.

Cupples, J., \& Ridley, E. (2008). Towards a heterogeneous environmental responsibility: Sustainability and cycling fundamentalism. Area, 40(2), 254-264.

Debord, G. (2006). Situationist Theses on Traffic. In K. Knabb (Ed.), Situationist International 
Anthology. Retrieved from http://library.nothingness.org/articles/SI/en/display/316

Defelipe, S. (2015, October 28). ¡Péguese la rodadita! Bogotá pedalea en más de 20 colectivos urbanos de ciclistas. Retrieved 13 July 2019, from Cívico website:

https://www.civico.com/bogota/noticias/peguese-la-rodadita-bogota-pedalea-en-mas-de-20colectivos-urbanos-de-ciclistas

England, M. R., \& Simon, S. (2010). Scary cities: Urban geographies of fear, difference and belonging. Social \& Cultural Geography, 11(3), 201-207.

Fenster, T. (2005). The Right to the Gendered City: Different Formations of Belonging in Everyday Life. Journal of Gender Studies, 14(3), 217-231.

Ferrell, J. (2011). Corking as community policing. Contemporary Justice Review, 14(1), 95-98.

Flusty, S. (2000). Thrashing Downtown: Play as resistance to the spatial and representational regulation of Los Angeles. Cities, 17(2), 149-158.

Furness, Z. (2007). Critical Mass, Urban Space and Vélomobility. Mobilities, 2(2), 299-319.

Galvis, J. P. (2014). Remaking Equality: Community Governance and the Politics of Exclusion in Bogota’s Public Spaces. International Journal of Urban and Regional Research, 38(4), $1458-1475$.

Gamble, J. (2017). Experimental Infrastructure: Experiences in Bicycling in Quito, Ecuador. International Journal of Urban and Regional Research, 41(1), 162-180.

Gray, N. (2018). Beyond the Right to the City: Territorial Autogestion and the Take over the City Movement in 1970s Italy. Antipode, 50(2), 319-339.

Harvey, D. (2008). The Right to the City. New Left Review, 53.

Henderson, J. (2006). Secessionist Automobility: Racism, Anti-Urbanism, and the Politics of Automobility in Atlanta, Georgia. International Journal of Urban and Regional Research, 30(2), 293-307.

Hoffmann, M. (2016). Bike Lanes Are White Lanes: Bicycle Advocacy and Urban Planning. Lincoln: University of Nebraska Press. 
Huizinga, J. (1949). Homo ludens: A study of the play-element in culture. London: Routledge \& Kegan Paul.

Klinke, I. (2016). Self-annihilation, nuclear play and West Germany’s compulsion to repeat. Transactions of the Institute of British Geographers, 41(2), 109-120.

Kofman, E., \& Lebas, E. (1996). Introduction. In E. Kofman \& E. Lebas (Eds.), Writings on cities. Oxford: Blackwell.

Kotányi, A., \& Vaneigem, R. (2006). Basic Program of the Bureau of Unitary Urbanism. In K. Knabb (Ed.), Situationist International Anthology (pp. 8-12). Retrieved from http://www.bopsecrets.org/SI/urbgeog.htm

Lefebvre, H. (1968). Le droit à la ville. Paris: Anthropos.

Lefebvre, H. (1996). The Right to the City. In E. Kofman \& E. Lebas (Eds.), Writings on cities. Oxford: Blackwell.

Lefebvre, H. (2004). Rhythmanalysis: Space, time and everyday life. A\&C Black.

Lefebvre, H. (2014). Critique of Everyday Life. London and New York: Verso.

López León, L. (2016). Pedalear en la red: Bicicleta, ciudad y movimiento social. Antropología Experimental, $0(16)$. Retrieved from https://revistaselectronicas.ujaen.es/index.php/rae/article/view/3017

Manderscheid, K. (2014). The Movement Problem, the Car and Future Mobility Regimes: Automobility as Dispositif and Mode of Regulation. Mobilities, 9(4), 604-626.

Mann, J. (2015). Towards a politics of whimsy: Yarn bombing the city. Area, 47(1), 65-72. Mayer, M. (2009). The 'Right to the City' in the context of shifting mottos of urban social movements. City, 13(2-3), 362-374.

Merrifield, A. (2013). Politics of the Encounter : Urban Theory and Protest under Planetary Urbanization. Athens: University of Georgia Press.

Montero, S. (2017). Worlding Bogotá’s Ciclovía From Urban Experiment to International "Best Practice”. Latin American Perspectives, 44(2), 111-131. 
Morhayim, L. (2018). Nightscapes of Play: Enjoyment of Architecture and Urban Space through Bicycling. Antipode, 50, 1311-1329. https://doi.org/10.1111/anti.12400

Mott, C., \& Roberts, S. M. (2014). Not Everyone Has (the) Balls: Urban Exploration and the Persistence of Masculinist Geography: Not Everyone Has (the) Balls. Antipode, 46(1), 229245.

Purcell, M. (2013). The right to the city: The struggle for democracy in the urban public realm. Policy \& Politics, 41(3), 311-327.

Purcell, M. (2014). Possible Worlds: Henri Lefebvre and the Right to the City. Journal of Urban Affairs, 36(1), 141-154.

Raquel, R. (2018). Mulheres em bicicleta: mobilidades urbana e direito à cidade. Para Onde!?, $9(2), 68-74$.

Rinaldi, F. J. (2018). El Biciactivismo en ciudades emergentes. El caso del Biciespacio en Posadas. Revista Transporte y Territorio, 0(19), 17-34-34.

Sagaris, L., \& Landon, P. (2017). Autopistas, ciudadanía y democratización: La Costanera Norte y el Acceso Sur, Santiago de Chile (1997-2007). EURE, 43(128), 127-151.

Samara, T. R., He, S., \& Chen, G. (Eds.). (2013). Locating right to the city in the Global South. Abingdon, Oxon ; New York, NY: Routledge.

Servín-Ugarte, C. (2014). El derecho a la ciudad: una propuesta de desempaque a partir del estudio de la movilización contra la vía exprés en Guadalajara, México. Revista de Derechos Humanos y Estudios Sociales, 6(12), 107-121.

Sheller, M. (2018). Mobility Justice: The Politics of Movement in an Age of Extremes. Verso Books. Sheller, M., \& Urry, J. (2006). The new mobilities paradigm. Environment and Planning A, 38(2), $207-226$.

Shepard, B. (2011). Play, Creativity, and Social Movements: If I Can't Dance, It's Not My Revolution. New York: Routledge.

Simone, A. (2005). Urban Circulation and the Everyday Politics of African Urban Youth: The Case 
of Douala, Cameroon. International Journal of Urban and Regional Research, 29(3), 516532.

Sosa López, O. (2017). Urban Mobility and Politics in Mexico City: The Case of the Frente Amplio contra la Supervía. Latin American Perspectives, 44(2), 184-204.

Spinney, J. (2009). Cycling the City: Movement, Meaning and Method. Geography Compass, 3(2), $817-835$

Stehlin, J. (2015). Cycles of Investment: Bicycle Infrastructure, Gentrification, and the Restructuring of the San Francisco Bay Area. Environment and Planning A, 47, 121-137.

Stevens, Q. (2007). The Ludic city: Exploring the potential of public spaces. London: Routledge. Stratford, E. (2016). Mobilizing a Spatial Politics of Street Skating: Thinking About the Geographies of Generosity. Annals of the American Association of Geographers, 106(2), $350-357$.

Torres, A., Sarmiento, O., Stauber, C., \& Zarama, R. (2013). The Ciclovía and Cicloruta Programs: Promising Interventions to Promote Physical Activity and Social Capital in Bogotá, Colombia. American Journal of Public Health, 103(2), 23-30.

Torres Barragán, C. (2015). Usos cotidianos y populares de la bicicleta en Bogotá. RevistArquis, 1(7). Retrieved from http://www.revistas.ucr.ac.cr/index.php/revistarquis/article/view/19983 UN-Habitat. (2016). The Right to the City and Cities for All. New York: United Nations Conference on Housing and Sustainable Urban Development.

Urry, J. (2004). The ‘System’ of Automobility. Theory, Culture \& Society, 21(4-5), 25-39.

Valentine, G. (2008). Living with difference: Reflections on geographies of encounter. Progress in Human Geography, 32(3), 323-337.

Van Neste, S. L., \& Sénécal, G. (2015). Claiming Rights To Mobility Through The Right To Inhabitance: Discursive Articulations from Civic Actors in Montreal. International Journal of Urban and Regional Research, 39(2), 218-233.

Vanolo, A. (2018). Cities and the politics of gamification. Cities, 74, 320-326. 
Verlinghieri, E., \& Venturini, F. (2018). Exploring the right to mobility through the 2013 mobilizations in Rio de Janeiro. Journal of Transport Geography, 67, 126-136.

Verso Books. (2017). The Right to the City: A Verso Report. London: Verso.

Walz, S. (2010). Toward a ludic architecture: The space of play and games. Pittsburgh: ETC Press.

Wood, A. (2015). The Politics of Policy Circulation: Unpacking the Relationship Between South African and South American Cities in the Adoption of Bus Rapid Transit. Antipode, 47(4), $1062-1079$.

Woodyer, T. (2012). Ludic geographies: Not merely child's play. Geography Compass, 6(6), 313326. 